\title{
Empathic projection in the films of the Dardenne brothers RICHARD RUSHTON
}

A number of commentators have engaged with the moral or ethical dimensions of the feature films of Jean-Pierre and Luc Dardenne; rather less attention has been paid to their style. What has been written of the films' stylistic traits - and my focus here is on La promesse/The Promise (1996), Rosetta (1999), Le fils/The Son (2002), L'enfant/The Child (2005), Le silence de Lorna/The Silence of Lorna (2008) and Le gamin au vélo/The Kid with a Bike (2011) - has most often been a matter of linking style to the films' moral messages. Some key terms describing that style have emerged from this context, with terms such as 'proximity' and 'realism' prominent among them. The former denotes the Dardennes’ penchant for placing the camera very close to characters' bodies, while the latter relates to commentators' praise for the Dardennes' 'responsible realism' or 'sensuous realism'. ${ }^{1}$ Such claims are certainly valid, though they could be more nuanced. This essay focuses on aspects of style in the Dardennes’ films, but does not aim to link these stylistic procedures to notions of ethics, concentrating instead on the tension between realist and modernist styles. I then relate these stylistic traits to the ways in which the films evoke emotional sympathy in viewers while also producing a sense of detached distanciation. This dual mode, that combines realism with modernism as well as sympathy with distanciation, provides a very particular sort of viewing experience. Drawing on the writings of art historian Michael Fried, as well as those of philosopher Stanley Cavell, I call this experience one of ‘empathic projection’.

Daniel Frampton claims that the films of the Dardenne brothers 'almost entirely reject some key conventions of fiction filmmaking (shot/reverse shot, point of view 
shots, establishing shots, and so on) in favour of a close and empathic form'. ${ }^{2}$ In doing so, Frampton claims, 'the films show us a concern, an empathy for the characters'. ${ }^{3}$ This empathic relationship, he continues, is created for the most part by the camera placing us very close to the characters. In The Son, for example, 'There is almost no space, no measurable distance between filmgoer/film and father'. What is thus created is 'a pure relationship between character and filmgoer'. ${ }^{4}$ Frampton then theorizes this pure relationship in terms of a notion of 'being-with', inspired by Martin Heidegger’s conception of Mitsein. All of this adds up to an attractive characterization of what the Dardennes are doing: an empathic form of filmmaking and film viewing combined with a philosophically inspired bodily fusion of characters and filmic space. These are powerful statements, and are in fact somewhat overstated. Frampton claims that there is almost no space between filmgoer and character, but the almost is significant, for the space between filmgoer and character is an important aspect of the Dardennes' style. And as for a 'pure relationship' between filmgoer and character, I am uncertain as to whether such a thing exists, for all relationships are mediated in ways that render them impure in one way or another - that is what makes them 'relationships'.

Like Frampton, Joseph Mai stresses the ways in which the Dardennes reject conventional modes of filmmaking. Their films and many of the scenes within them start in the middle of the action - in media res - so that, as Mai puts it, 'The Dardennes' frames emphasize a lack of external point of view'. ${ }^{5}$ Often viewers enter the action without quite knowing what is happening, where the action is set or where it is going. Of significance here is the minimal use of establishing shots. Mai also notes that the Dardennes favour long takes, and few commentators would disagree: the plan séquence is indeed one of the main components of the Dardennes' style. 
Mai focuses on the Dardennes' own conception of a 'body-camera' (corpscaméra). This term describes how the camera acts like another body at the scene of the action - the handheld shooting so often used in the Dardennes' films certainly gives the impression of a camera that is attached to a body, a body that moves, shakes and turns its head like a human. Additionally, the notion of the body-camera is one that describes the particular connection the Dardennes' camera has with the bodies of characters, and we have already seen Frampton hinting at this idea. With the camera itself acting like a body, Mai claims, both it and we are drawn into a bodily relationship with the characters in the films. Here, then, 'vision is not an independent entity, but is reseated in the body, or rather in two bodies involved in a dancelike movement through other bodies'. ${ }^{6}$ Mai thus claims that the Dardennes offer a vision that is not merely optical but also, or predominantly, bodily and 'haptic'.

In common with many other commentators, Sarah Cooper argues that the Dardennes aim for 'novelty', that they want to 'break cinematic codes' and 'shake cinematic preconceptions' ${ }^{8}$ Like Frampton, Cooper claims that that the camera and the viewer are to some extent with characters ('being-with'), but also and crucially that the camera is ever so slightly removed. The camera is more often than not behind characters, so that 'our frequent point of view is of some part of their backs' ${ }^{9}$ This is an important point for Cooper, because it means viewers do not straightforwardly identify with characters: we do not see from characters’ point of view but instead from slightly behind them. Of the Dardennes’ characters - pointing specifically to Igor (Jérémie Renier) in The Promise, Rosetta (Émilie Dequenne) in Rosetta and Olivier (Olivier Gourmet) in The Son - Cooper writes that 'we see them without being able to be them' and, as a result, we are 'position[ed] firmly outside of the characters' lives'. ${ }^{10}$ In short, 
we do not identify with characters in the ways that we seem to identify with characters in many conventional films.

These claims lead to what is Cooper's most interesting point regarding the Dardennes' style. While identification in the cinema has traditionally been a matter of 'stepping into someone else’s shoes', what occurs with the Dardennes' filmmaking is more akin to what Cooper calls 'substitution'. ${ }^{11}$ (Cooper’s analysis is heavily influenced by French ethical philosopher Emmanuel Levinas, for whom 'substitution’ is a key term.) This is a matter of being placed close to the characters, without being put in the same place as the characters, and Cooper argues that this occurs as a process of proximity rather than one of straightforward empathy or identification. Luc Dardenne has himself named this aspect of the brothers' filmmaking, calling this distance between the camera and character the space of the 'secret'. ${ }^{12}$ This is precisely a space of the unknown and the unknowable, because we can never truly know what another person is thinking or feeling or seeing - it is 'secret'. By way of the secret, therefore, the mystery and otherness of the other person is respected and maintained. We do not presume to know what the other person is seeing, thinking or feeling. We do not identify with them. For Cooper, it is this distance from characters maintained by the camera that allows for the very particular effect of the Dardennes' style. We get very close to characters, but are never quite with them. She sums up her points in the following way: It explains how we can be moved without replicating or sharing the embodied emotions we see on screen ... to engage with the soul of these films is thus to replicate the impossibility of stepping into the characters' positions to see as they see, to feel as they feel. ${ }^{13}$

Each of these approaches to the Dardennes' style offers a rich engagement with the particularities of the camerawork and the senses of address offered by the films. For 
Frampton, emphasis is placed on the notion of being-with, while for Mai the 'dance' of the body-camera is paramount. Cooper, significantly, places emphasis on the minimal distance the camera keeps from the characters, so that the viewer's vision of events and sympathy for the characters is always at one remove from the experiences of the characters themselves. Much could be made of these aspects of the Dardennes' techniques using Murray Smith’s distinction between allegiance and alignment, according to which, allegiance pertains to the Dardennes’ central characters but not to character alignment. Subjective access - that is, access to the internal subjective states of characters, or what Smith calls 'alignment' - is very much downplayed in the Dardennes' films. ${ }^{14}$ However, the stakes of their techniques owe more to the contexts of modernist aesthetic strategies than Smith might be prepared to countenance.

In a short journalistic piece published in 1999 in Cahiers du cinéma, Jacques Rancière discusses Rosetta in terms of a combination of realist and modernist tendencies. ${ }^{15}$ Surprisingly, no commentators appear to have followed up Rancière’s approach, for it opens up some interesting ways of thinking about the Dardennes’ style. While the commentators examined so far all attribute a certain singularity to that style, Rancière instead proposes a double process. Where these commentators base their analyses on an ‘either/or' logic in the Dardennes’ style, Rancière discovers a logic of 'both/and'.

The notion of doubling opens up some fertile theoretical terrain. In what follows, I call upon a number of doubled terms, though not in order to resolve them or to favour one term over the other. Rather, I examine how these terms work together in the Dardennes' films. I explore primarily the terms of realism/modernism and sympathy/distanciation, but those of immersion/specularity and display/privacy are also in contention. These pairs of terms eventually lead to the notion of 'empathic 
projection'. We have already seen some sense of this term emerge in Cooper's reflections, for empathic projection is essentially the imaginative act of putting yourself in some else's shoes: that is, not being in someone else's shoes, but imagining what it might be like; to try to think what another person is thinking, to feel what another is feeling. These issues are central to the Dardennes’ stylistic concerns.

Rancière, in his short piece on Rosetta (which also discusses Bruno Dumont’s L'Humanité [1999]), opens up the dimensions of the Dardennes' double strategy, and finds that this doubling occurs at two levels - the doubling is itself doubled. At the level of narrative the doubling consists of realist description and generic theme, while at the level of style Rancière again claims that the Dardennes adopt realist strategies despite remaining resolutely modernist. Rancière’s point is that neither of these strategies typically belongs together: narrative realism is usually opposed to the cliches of genre, whereas the Dardennes manage to place realism and genre on the same plane. Much the same goes for style: realism has typically been placed in opposition to modernism, so for the Dardennes to combine realism with modernism is something of a double play. ${ }^{16}$ At the level of narrative in Rosetta, therefore, a description of the sordid, embattled conditions of everyday life - of Rosetta’s day-to-day struggle to stay alive is combined with a generic appeal to the classic theme of the 'dignity of the people'. Thus the film deploys two intertwined aspects of narrative style. The first of these is indebted, so Rancière argues, to Gustave Flaubert - Rancière calls it a 'Bovary effect'. Attention to the detail and minutiae of material existence - exemplified by Rosetta's rituals of changing her shoes for boots, of caressing her painful belly with her hand and warming it with a hairdryer, of rigging a makeshift fishing contraption in order to obtain some food - along with the many brutal closeups of her pained, desperate and determined expressions (Rancière calls them 'monstrous'), are related to a line of realist 
description in the film that is indebted to nineteenth-century novelists such as Flaubert. ${ }^{17}$ But it is not only realist depiction that is at stake, for Rosetta also fulfils the elements of a classic (albeit modern) genre: that of the 'dignity of the people'. ${ }^{18}$ The Dardennes offer tales of the virtues and grandeur of 'the people', and Rosetta is certainly a representative ‘type'. Such types are related to the Brechtian Gestus, a link made by Rancière, but they might also be related to Eisensteinian typage as much as to Victor Hugo’s larger-than-life representative types. Rancière thus discovers two aspects of narrative style: realism combined with a classic generic theme.

At the level of style, realism is certainly prominent, and most commentators on the Dardennes attribute to them a realism of one order or another. But Rancière’s eyebrow-raising claim is that realism in Rosetta is combined with a modernist stylistic impulse indebted to Brechtian mannerism. In this respect, Rancière goes so far as to label Rosetta ‘Daughter Courage’ (after Brecht’s Mother Courage). ${ }^{19}$ For Rancière, then, the Dardennes' method is indebted to various strategies of realism, but this realism is combined with a modernist didacticism, as though Rosetta is very much a 'learning film’ in the manner of Brecht's notion of the Lehrstück.

To draw out Rancière’s claim of doubling, some fairly detailed analysis of specific scenes from the Dardennes' films is necessary, but a close focus on these aspects can shed light on the stylistic operations shared by the films. The consequences of the analysis of these scenes and their modes of doubling can ultimately be articulated in terms of 'empathic projection'.

While it seems generally to be true, as already noted, that there are virtually no point-of-view shots, shot/reverse-shots, establishing shots or suturing effects in the Dardennes' films, and while it is also the case that the Dardennes' camera often films the backs of characters or the backs of their heads, other repeated procedures in the 
films appear to have been overlooked. What is extremely common is the use of a twoshot from medium distance, about waist high. This allows for the long takes that give the scenes the realism identified by many commentators, but significantly this two-shot long take combines with what may be the Dardennes' most persistent cinematic technique: a single take of a conversation between two characters in which a handheld camera moves back and forth between the interlocutors. The strategy seems indebted to direct cinema, not surprisingly given the Dardennes’ many years as documentary filmmakers, and is one that also features prominently in the work of contemporary North American independent filmmakers such as Hal Hartley and Richard Linklater. The back-and-forth movement produces a sense that the camera is there on the scene, capturing raw events as they unfold. It is significant, too, that this method works as something of a replacement for the shot/reverse-shots found in more traditional conversation setups. Instead of viewing characters more or less face-on or in threequarter face, we tend to view them from side-on as they speak to each other. This sideon view seems every bit as prevalent, if not more so, as the brothers' more famed view from the behind the head.

Many scenes in the Dardennes' films hinge on this combination of two-shot and back-and-forth conversation structure. Quite early on in The Promise, for example, Igor arrives late for work at the garage where he is apprenticed. During the conversation that ensues between Igor and the mechanic, we very rarely see the two characters framed together in a single shot, but instead the handheld camera moves back and forth in an agitated way between the characters, its movements jittery and inexact. The mechanic berates Igor for his lateness, Igor blames his tardiness on his father, and then the mechanic comments on the tattoo on Igor's arm. 
The Promise, contains scenes throughout in which two characters are framed in the same shot from about waist height or a little more tightly, for example when Igor and Roger (Olivier Gourmet) sing a duet at the karaoke bar, or towards the end of the film when Assita (Assita Ouedraogo) stands at the side of the road with her sick baby, trying to hitch a lift to hospital. Igor approaches her and she asks him whether her husband, Amidou (Rasmane Ouedraogo) is dead; 'He’s not dead', Igor lies. This is all captured in a close two-shot - from about chest up for each of the characters - with each character side-on to the camera.

The crucial final scene at the train station combines the two-shot and the backand-forth in a single setup. ${ }^{20}$ Assita walks towards the platform with Igor beside her, while the camera travels alongside them both. As Assita turns to go up the station steps (she is purportedly going to visit relatives in Italy), Igor finally tells her the truth about Amidou's death. The rest of the scene unfolds in one continuous take. The camera follows Assita briefly as she stops on the second or third step (Igor is no longer in the shot), then sways back to capture Igor, cutting Assita out of the frame. 'He fell from scaffold', Igor says. As he continues to explain, the camera sways back to Assita; we see her from behind, and this time Igor is pushed out of the frame. The camera sways again back to Igor before finally returning to Assita. She comes back down the steps and turns to face him - both are now in the frame - and in the final shot of the film they walk away together, back in the direction from which they came. This shot thus features a number of sways back-and-forth, while also allowing for moments in which both characters are in the frame (what I have been calling a 'two-shot'). ${ }^{21}$

The Dardennes' camera is perhaps at its most restless in Rosetta, and certainly on a par with The Son in this regard, but there are significant moments when the twoshot setup is used. Midway through the film, Rosetta goes after work with Riquet 
(Fabrizio Rongione) to his flat, where they chat over dinner and a beer. In the central and longest shot of the scene, both are seated at a table with the camera, very still, framing them in a two-shot composition. When Riquet gets up from the table to grab another beer from the fridge, the camera follows his actions - thus leaving Rosetta out of the shot - and when he subsequently returns to the table and sits back down, the camera resumes its stillness and framing of both characters.

Later in the film, when Rosetta has told the waffle boss (Olivier Gourmet) that Riquet is swindling him by selling waffles on the side, the confrontation that ensues in the waffle cart unfolds in a single take. As the boss fires Riquet, the camera is momentarily located alongside Rosetta at the back door of the cart, 'watching' the confrontation between the two men. The camera then sways back to a close view of the side of Rosetta's face as she watches the events. Rosetta intervenes in order to show the boss where Riquet has hidden the extra waffles he proposes to sell, and the camera follows her actions. Rather than a two-shot, here we have a three-shot - with all three characters in the frame. We are shown a range of relationships between the characters, while never seeing events from anyone's particular point of view. At the same time there is a sense in which the camera seems something of an observer, and thus we too feel we are there 'on the scene' - watching events unfold before our very eyes.

In The Kid with a Bike, the young boy Cyril (Thomas Doret) finally tracks down and visits his father, Guy (Jérémie Renier), at a restaurant, where he is preparing food in anticipation of the lunchtime opening. For the first quarter of the film Cyril has been searching desperately for his father, so this scene is a crucial one. The central shot is again a very long continuous take. It begins with a simple two-shot as Cyril and Guy chat at what seems to be a drinks service counter; the camera then swings around to follow Guy as he walks to the kitchen area to continue his prepping for the lunch 
service. Cyril follows him and they talk together; Guy unpacks some food and stirs some pots, then lets Cyril do some stirring too. Both of the characters are in the shot, but seen from a far greater distance than in the passages from The Promise and Rosetta discussed above. The same features apply, however: a mobile camera that follows the movements of characters as they converse; a typical two-shot setup featuring a pair of characters in frame as they speak to each other; no point-of-view shots and no shot/reverse-shot setups. In the middle of this, Guy summons up the courage to say to Cyril, 'I can't have you back', delivering the declaration that he is abandoning his son.

There are two notable outcomes of these setups that seem to typify the Dardennes’ filming methods. While Frampton’s conception of ‘being-with’, Mai’s notion of dancelike bodies and Cooper's analysis of proximity all illuminate the Dardennes' techniques to some extent, the setups discussed here disclose a slightly different and more important stylistic conception, and deliberately retard access to the interior of characters. They do not allow us to get 'inside' a character in the way that many Hollywood (and other) films do, which is to some extent a result of the fact that we rarely get to see a character face-on. We are more likely to see them from behind or, as I have described, from side-on. It is tempting to declare the Dardennes' strategy as the direct opposite of the front-on, shot/reverse-shots revered by a director such as Ozu Yasujiro, who typically has his characters in full face, looking almost directly at the camera. Where Ozu favours editing between characters, the Dardennes eschew editing in favour of the plan sequence, with two characters occupying the frame while in conversation, combined with a back-and-forth between them. Like Ozu, the Dardennes still favour a closeness to characters, but the handheld camera usually makes this closeness feel jittery and disturbing. This contrast with Ozu is interesting, for the fronton, full faces of his conversation sequences impress upon us the honesty or sincerity of 
his characters - their faces are rendered ‘open’, as it were. The Dardennes’ characters, by contrast, impress upon us a kind of 'hiddenness', as though they are hiding something within themselves - their faces are 'closed'. ${ }^{22}$ This phrase is significant. The Dardennes' techniques I have been describing - a two-shot and a back-and-forth - are also combined with a blankness of expression in the characters that is, in ways noted by Rancière, positively Brechtian. ${ }^{23}$ More accurately, perhaps, the Dardennes’ debt here, which they willingly acknowledge, is to Robert Bresson. Igor, Rosetta, Bruno, Olivier, Lorna and Cyril are all in a sense 'blank', lacking expressive depth. ${ }^{24}$ Because we very rarely get to see characters face-on, or even in three-quarter shot, our access to them to their 'insides' - is very deliberately blocked.

In general terms this is a feature of the combination of realism and modernism: realism gives us detail, while modernism delivers a certain abstraction. At the level of narrative, realism gives us something that seems realistic - the handheld camera, its shakiness that appears to place us 'on the scene of reality', the chronicling of the details of everyday life and the struggle to stay alive - while the generic elements also make the narrative mannered, as though we were being exposed to morality tales or fables rather than to realist narratives. Some commentators have criticized the films for this, as though the Dardennes were merely pretending to be realists while actually offering melodramatic morality tales - the combination of realism and generic theme dismissed as an aberration, the generic traits undermining the call to reality. David Walsh is especially critical: 'In the end, the filmmakers are reduced to moralizing about what individuals do and wagering on their capacity to listen to their better selves. ... This comes perilously close to middle class sermonizing, preaching virtue to the downtrodden. 25 
I would propose a rather more sympathetic take on the Dardennes' combination of realism and mannerism-modernism. If their characters seem to lack expressive depth or to be hiding their thoughts and feelings from us, this does not mean emotional depth or content is lacking - quite the contrary, in fact. Unlike the overt emotional displays typical of many Hollywood films, the constrained expressions of the Dardennes’ characters make us think they are bottling up their emotions deep within, so that we do not think these characters are unemotional but instead that they must be so overcome with emotion that they cannot even outwardly express it. ${ }^{26}$ The Dardennes' characters do not display their emotion as though it were a public product or sign; they keep their emotions private, inside, to themselves. ${ }^{27}$

The Dardennes’ films therefore offer what seems to be a very different emotional engagement from that typically produced in mainstream cinema. In this regard it is distinct from what Carl Plantinga has called 'the scene of empathy'. Plantinga describes such scenes in Hollywood films as typically involving a closeup of a character offering a display of emotion which viewers may then, in one way or another, 'catch'. Drawing on terms from cognitive psychology - 'affective mimicry' and 'emotional contagion' - Plantinga's claim is that 'the viewer shares some of the experience the character is thought to have, possibly in an automatic and unconscious way'. ${ }^{28}$ This kind of experience - the scene of empathy - is most likely to occur in what Plantinga calls sympathetic narratives, which he contrasts with distanced narratives. The former use techniques favouring emotional absorption and bold solicitation of emotion, while the latter are more reflexively selfconscious and defamiliarizing. ${ }^{29}$

The Dardennes, we might think, tend towards these selfconscious and defamiliarizing cinematic forms, placing their filmmaking at odds with Hollywood's overt emotional displays: in other words, they seem to offer distanced narratives rather 
than sympathetic ones. Plantinga charts in Brechtian terms a distinction between the kinds of films that eschew overt emotion - distanced narratives - and those that feature bold emotional displays - sympathetic narratives: distanced narratives enable thought, while sympathetic narratives disable thought. But he is also very critical of the simplicities implied by this distinction: 'there is nothing', he argues, 'in the elicitation of strong sympathetic emotions that prima facie could be said to disable critical thought. Sympathetic emotions may also encourage critical thought about social and political conditions. $^{30}$

While Plantinga maintains a distinction between sympathy and distanciation in order to claim that the scene of empathy, sympathy or emotional display in a film does not necessarily retard critical engagement - he favours sympathetic narratives - I want to claim instead that what is integral to the Dardennes’ strategy, allied with their doubling of realism with modernism, is a combination of sympathy and distance. In trying to make sense of this combination, it is important to bear in mind its intention: what it is the Dardennes are trying to do, and what the point of their strategies might be. It may relate to Plantinga's claim that if we are to be emotionally engaged by films then there must be occasions when 'the viewer shares some of the experience the character is thought to have'. ${ }^{31}$ This sharing of a character's experience will amount, in due course, to an experience of empathic projection, of imagining what it is like to be in someone else's shoes. If we share some of the experiences of the Dardennes' characters - and I think if we are at all interested in these films that we do - then as I have already stated, this sharing is not a result of seeing things from the characters’ point of view. But nor do we share these characters' emotions by virtue of their overt emotional displays: there are no emphatic 'scenes of empathy' such as those foregrounded by Plantinga. In the Dardennes' films, where we are typically offered only a side-on view of a face or are 
confronted by a character's back, there is most often a reservation about the display of emotion, a certain blankness or bottling up of feeling in the characters. ${ }^{32}$

What we are faced with in the Dardennes' characters is in fact what Fried calls 'absorption' in painting. I have previously attempted to draw upon Fried’s notion of absorption for thinking about cinema, such that absorption comes close to describing the kind of narrative engagement - being 'caught up in a narrative' - that pertains to the classical narrative cinema in ways similar to Plantinga's notion of sympathetic narratives. ${ }^{33}$ Fried contrasts absorption with theatricality, where theatricality in the first instance designates a kind of distanciation. To be boldly Brechtian about such issues, absorption indicates 'narrative enchantment' while theatricality indicates a certain 'knowingness' and self-reflexivity about the conditions of address - a knowingness of display, an understanding that any work of art is a type of theatre addressed to an audience. In short, Fried's distinction between absorption and theatricality could be said to map easily onto the distinction drawn above between sympathy and distanciation.

And yet these distinctions are not so clear cut. If theatricality designates an overt display to, and solicitation of, the viewer's attention and responsiveness, then the sympathetic scene of empathy described by Plantinga would seem to fit that description, being an overt display of emotion that viewers are supposed to catch. In other words, this raises the issue of whether sympathy might denote some kind of absorption in a cinematic narrative or whether, conversely, it is of a rather more theatrical design. And if my claim here is that the Dardennes combine sympathy and distanciation, this merely seems to confuse further any notion of absorption or theatricality. And if I am trying to work towards a point in the Dardennes' films at which 'the viewer shares some of the experience the character is thought to have' - that is, experiences empathic projection - 
then in what ways can terms like sympathy, distanciation, absorption or theatricality help in clarifying this kind of experience?

In his recent work, Fried has tried to chart a kind of prehistory of absorption, in which he argues that Caravaggio is probably the first painter in the western tradition to 'discover' absorption. This discovery was a matter of painting figures that were in many ways inexpressive, lacking in overt emotional display. Yet far from concealing emotional expression, this inexpressiveness instead allowed viewers to project emotional intensity onto or into the depicted figures. It is this projection that brings about the discovery of absorption, which Fried calls 'a momentous discovery':

the discovery that a powerful mode of emotional communication can be actuated by absolutely minimal physiognomic and gestural means. Put slightly differently, the discovery concerns what viewers, confronted with certain sorts of outwardly almost wholly inexpressive figures ... spontaneously do ... namely, read that lack of outward expression as an unmistakable sign of intense inwardness and sheer depth of feeling. ${ }^{34}$

Fried argues that it is the modes of expressive restraint in painting that granted certain subjects in Caravaggio's canvases the suggestion of deep interior feeling, a depth that was sensed and projected by viewers of these paintings in a manner that, after Cavell, Fried calls ‘empathic projection’ (Fried’s specific example here is Caravaggio’s Penitent Magdalen [1596-97]). ${ }^{35}$

A similar depth of emotional sense can be attributed to the lead characters in the Dardennes' films. This seems to me to be a product of their performative restraint and blankness, which along with the side-on shots of their faces allows viewers to empathically project a great depth of feeling onto or into these characters. On this count, then, empathic projection occurs when, in Plantinga's words, 'the viewer shares some of 
the experience the character is thought to have'. That sharing is, however, a matter of the viewer remaining separate from the character and projecting feelings or thoughts onto or into that character. In short, this notion is not one of seeing things from a character's point of view or of 'feeling the same feelings' as a character; rather, it is one of being cut off from but nevertheless emotionally connected to a character at one and the same time. In short, there is both a distance maintained from the character as well as a sympathy or closeness with the character. Absorption and empathic projection therefore require a combination of sympathy and distanciation.

A final set of terms will perhaps clarify what is occurring here. As part of his prehistory of absorption, Fried tries to theorize the way in which Caravaggio approached the act of painting. To do this, Fried comes up with a pair of terms: immersion and specularity. Fried makes a distinction between two 'moments' which might be said to characterize what is at stake in many of Caravaggio’s works. These moments are integral to Caravaggio’s method of painting identified by Fried, but Fried also understands the painter - here Caravaggio - as being the first viewer of the painting, so for Fried these moments pertain also to the act of viewing. The first moment is the one of actually making the painting, and Fried attempts to describe this in terms of what he calls immersion, because the act of painting is one of trying to get into the picture, to be as close to the objects being painted as possible, to the point of being fused with the painting. Fried writes,

I call the 'moment' immersive, imagining the painter as so caught up, so immersed, in this phase of his work on the painting ... as to be less than fully aware of any sharp distinction between the painting and himself. ${ }^{36}$ 
To take this a step further, Fried refers to this moment as one that involves the body inasmuch as it accords with a desire for the painter to enter bodily the space of the painting. ${ }^{37}$

The notion of immersion is one of going into the painting, and I would like to claim that not only does a similar sense of immersion come into play in cinema - the sense in which a spectator will forget him or herself and be fused with the image, with the mise-en-scene, the characters and their actions - but also that this is especially relevant for the Dardennes' style. As we have seen, commentators are keen to foreground the Dardennes’ notion of a body-camera, with Mai highlighting the idea of a dance of bodies between camera and character, and Frampton emphasizing the closeness of the camera in a manner of 'being-with'.

If, for Fried, immersion indicates one moment of Caravaggio’s method, then the other moment is one of specularity. If the moment of immersion is one in which the body of the painter-viewer is fused with what is inside the canvas - and for the cinema, the moment in which the spectator is fused with the screen images - then the specular moment is that of stepping back and away from the canvas in order to register what has happened there. It is a moment, writes Fried, 'of separating or indeed recoiling from the painting, of becoming detached from it, which is to say of no longer being immersed in the work but rather of seeing it, taking it in, as if for the first time'. ${ }^{38}$ The specular moment is the moment of reflection, of realizing - 'as if for the first time' - what has been occurring via one’s immersion. My contention is that the Dardennes' films perform precisely this kind of operation: intense moments of immersion which are followed - or, more strictly speaking, accompanied by - moments of specularity. Importantly, immersion and specularity form a couple or a 'double'. They go hand in hand, so that immersion already implies the split or break that will happen by 
way of specularity, and equally the specular moment cannot take place without the accompanying moment of immersion. There is an example of this in The Promise, when Roger hears that labour inspectors are about to descend on his worksite, which is full of illegal immigrant workers he has smuggled into Belgium. He hurriedly asks his son, Igor, to alert the illegal workers and clear the site. There are four shots to consider here.

In the first shot, having scrambled up house's staircase to the first floor, Igor leans out of a window and shouts up to the illegal worker Amidou, who is working higher up on the scaffolding, 'Amidou! Get outta here,' Throughout this shot the camera peers from ground level, at first framing Amidou but, as Igor sticks his head out of the window to shout, the camera joltingly moves so that Igor is now centred in the frame. There is no cutting, just the jagged handheld movement which replicates, it seems to me, the movements of an observer's head and eyes as they capture the action unfolding before them. Amidou scrambles to get onto a ladder that will enable him to leave the scaffolding and the camera sways back to him, in the characteristic back-and-forth movement. He hesitates and steps back to turn off his portable radio. All of this adds up to what I want to call immersion, a mode of camera movement and action - and thus of our seeing and experiencing - that tries to be ‘in’ the picture. The second shot, amid all this scrambling and panicking, shows Igor rushing back down the staircase, the camera observing him as he jolts around a corner where there is a small landing with a window (we are now inside the house). Has he heard something? He stops, goes back and peers out of the window. What can he see? The handheld camera, still jittery, follows Igor's movements. We are still in a mode of immersion. In the third shot Igor is now outside. The camera is just millimetres from Amidou's fallen body as Igor rushes to him. He turns Amidou over onto his back (we are still immersed). In the fourth shot we come upon the moment of specularity. The camera has now retreated to a position several 
metres away and is static, even though it clearly remains handheld, occupying the position of a detached, partially hidden observer. It has stopped its stuttering attempts to keep up with the actions of the scene. It is no longer a 'body-camera', which is to say its mode is no longer one of immersion; rather, the break or split has been made. Here is the moment of specularity: we see, at a distance, Igor bent over the prostrate body of Amidou. After another edit the camera moves back closer to the characters and one of the film's key moment ensues: the promise referred to in the film's title.

The example offered here is a small-scale one, but the Dardennes' films are full of this combination of immersion and specularity. A notion of immersion can fairly straightforwardly be seen as central to the Dardennes' techniques, There is a sense of being bodily conjoined with the image by way of a 'body-camera', in ways that encourage us to be in or fused with the image. Less attention seems to have been paid to the moments of clear repose, of 'cutting away', of distancing and separation, which are indicative of that mode or moment that Fried calls specularity. There are numerous key instances of specularity in the films: the much remarked-upon scene in Rosetta in which Rosetta recites a small poem to herself; Rosetta's moments of retreat to her caravan, which often involve her soothing her pained stomach with a hairdryer; the many shots of Bruno in The Child, combing the streets of Seraing (the camera typically remains distanced from these walks); a brief moment when Sonia hands the newborn Jimmy to Bruno to hold; when Bruno and Sonia hire a car and escape for a day out with their child; when Bruno stops to buy Sonia a jacket like his own; in The Son, when Olivier visits Francis’s (Morgan Marinne) small flat and lies down in his bed; at the end of Lorna, when Lorna (Arta Dobroshi) retreats to a small cabin in the forest.

I want to draw attention to one other moment that fuses immersion and specularity. Towards the end of The Kid with a Bike, Cyril rides his bike through the 
darkened streets of Seraing. He has been rejected by the local petty crime gangster, Wes (Egon Di Mateo), then rebuffed once again by his father, yet we see no tears on his face. The camera does not get close to him but stays at a distance, so we see him ride his bike as if he is riding to nowhere, fleeing. This a good example of a body-camera technique: the camera rides along with Cyril, flowing and floating in a dance-like manner which makes the spectator's bodily rhythms resonate with those of the boy ('The first escapes from childhood are by bike', Jean-Pierre Dardenne has declared). ${ }^{39}$ But this shot is surely also indicative of a moment of specularity. A crucial point in the plot has been reached - Cyril has been finally and categorically rejected by his father - and there is a sense of stepping back, of reaching a crossroads, of 'recoiling' and reflecting, of becoming detached and seeing things in a new light. Cyril knows for sure he will never return to live with his father, and he also knows he has mistreated the one person who has cared for him, Samantha (Cécile de France). All of these conflicting thoughts and feelings, a simultaneous embodiment and reflectiveness, immersion and specularity, are at play in this shot.

So what, in the end, is empathic projection? It is a matter of stepping into some else's shoes, but only imaginatively or projectively. It is never to actually be in those shoes, but is a matter of imagining what it might be like by way of projecting our own thoughts and feelings onto or into another person. ${ }^{40}$ In this way 'the viewer shares some of the experience the character is thought to have', as Plantinga puts it (though he does not, of course, use the language of 'empathic projection'). Empathic projection thus occurs by being simultaneously cut off from as well as emotionally connected with a character. It is, I would contend, composed of a combination of immersion and specularity. It is also a combination of sympathy and distance, and its effect in the 
Dardennes' films is indebted to the double strategy that combines a pulsating realism with modernist detachment.

In The Claim of Reason, Stanley Cavell describes empathic projection as being one way in which we can convince ourselves of the humanness of other humans:

there may just be other things for you to be, but ... my taking you for, seeing you as, human depends upon nothing more than my capacity for something like empathic projection, and ... if this is true then I must settle upon the validity of my projection from within my present condition, from within, so to speak, my confinement from you. For there would be no way of stepping outside my projections. $^{41}$

He adds that 'If I stopped projecting, I would no longer take anything to be human, or rather I would see no radical difference between humans and other things'. ${ }^{42}$ What is at issue for Cavell, therefore, is the matter of trying to understand or empathize with another person, while at the same time knowing that I can never be in that other person's place, that he can never totally be in their shoes or feel what they feel. Rather, separated from them, he can only project what the other might be feeling or thinking; he can only imagine what it would be like to be them. Cavell still has reservations - he is unsure that empathic projection goes quite far enough in understanding and appreciating the other person. He writes, 'I do not know whether empathic projection is, or is not, a sufficient basis for acknowledging the other's existence'. ${ }^{43}$ Acknowledgment requires something stronger than merely my own confinement, it also requires some sense of a promise that I can overcome that confinement. These are problems and challenges for humankind as much as they are for philosophy or cinema.

In short, this showing of how we can both be with characters and yet also be separated from them, both sympathetic and distanced, offers a precise demonstration of 
the problem of empathic projection. And perhaps that is ultimately what the Dardennes’ films are about, and what is at stake for both their characters and their viewers. How can we traverse the distance between one human and another, between me and you, between self and other? How, in effect, can we convince ourselves of the humanness of other humans?

${ }^{1}$ On proximity, see Sarah Cooper, 'Mortal ethics: reading Levinas with the Dardenne brothers', Film-Philosophy, vol. 11, no. 2 (2007), pp. 66-87; on responsible realism, see Philip Mosley, The Cinema of the Dardenne Brothers: Responsible Realism (London: Wallflower Press, 2013); on sensuous realism, see Joseph Mai, Jean-Pierre and Luc Dardenne (Urbana, IL: University of Illinois Press, 2010), p. 57.

${ }^{2}$ Daniel Frampton, Filmosophy (London: Berg, 2006), p. 145.

${ }^{3}$ Ibid., p. 146.

${ }^{4}$ Ibid., p. 147.

${ }^{5}$ Mai, Jean-Pierre and Luc Dardenne, p. 55.

${ }^{6}$ Ibid.

${ }^{7}$ Ibid., p. 55.

${ }^{8}$ Cooper, 'Mortal ethics’, p. 72.

${ }^{9}$ Ibid, p. 73.

${ }^{10}$ Ibid., p. 83.

${ }^{11}$ Ibid., p. 84.

${ }^{12}$ Luc Dardenne, Au dos de nos images, 1991-2005 (Paris: Éditions du Seuil, 2008), p. 130-31.

${ }^{13}$ Cooper, 'Mortal ethics’, p. 85. 
${ }^{14}$ Murray Smith, Engaging Characters: Fiction, Emotion and the Cinema (Oxford: Oxford University Press, 1995), pp. 82-84.

15 Jacques Rancière, 'Le bruit du peuple, l'image de l'art: a propos de Rosetta et L’Humanité', Cahiers du cinéma, no. 540 (1999), pp. 110-12.

${ }^{16}$ A recent work that does place realism alongside modernism is Lúcia Nagib, World Cinema and the Ethics of Realism (London: Continuum, 2011). The book does not, however, mention the Dardenne brothers.

${ }^{17}$ Rancière, 'Le bruit', p. 111.

${ }^{18}$ Ibid., p. 112.

${ }^{19}$ Ibid.

${ }^{20}$ On this scene also see Cooper, 'Mortal ethics', p. 71.

${ }^{21}$ David Bordwell notes that the use of a two-shot for conversations was fairly standard for classical Hollywood. Since the 1970s, however, the two-shot in Hollywood has been replaced by the use of rapid 'singles' for conversations. See David Bordwell, The Way Hollywood Tells It: Story and Style in Modern Movies (Los Angeles, CA: University of California Press, 2006), pp. 128-29.

${ }^{22}$ Paul Coates notes that the profile face in films most often denotes that a character is hiding something. See Coates, Screening the Face (Basingstoke: Palgrave Macmillan, 2012), pp. 29-35.

${ }^{23}$ On some of these issues, see Andrew Higson, 'Film acting and independent cinema', Screen, vol. 27, nos 3/4 (1986), pp. 110-32.

${ }^{24}$ On the relationship between the Dardennes and Bresson, see Mosley, The Cinema of the Dardenne Brothers, pp. 34-36.

${ }^{25}$ David Walsh, 'The Dardenne brothers: an argument for a far more critical appraisal, or, what about the “extenuating circumstances”?', in Bert Cardullo (ed.), Committed 
Cinema. The Films of Jean-Pierre and Luc Dardenne: Essays and Interviews

(Newcastle upon Tyne: Cambridge Scholars Press, 2009), p. 80.

${ }^{26}$ Richard Dyer notes a similar 'bottling up' of emotion in Celia Johnson’s performance in Brief Encounter (David Lean, 1945). The restraint of Johnson’s performance grants the film a realism that downplays its status as melodrama. Richard Dyer, Brief Encounter (London: BFI Publishing, 1993), pp. 32-39.

${ }^{27}$ On the distinction between display and privacy in film, see Andrew Klevan, Disclosure of the Everyday: Undramatic Achievement in Narrative Film (Trowbridge: Flicks Books, 2000), pp. 96-99.

${ }^{28}$ Carl Plantinga, Moving Viewers: American Film and the Spectator's Experience (Berkeley, CA: University of California Press, 2009), p. 127. Cf. Plantinga, 'The scene of empathy and the human face on film', in Carl Plantinga and Greg M. Smith (eds), Passionate Views: Film, Cognition and Emotion (Baltimore, MD: Johns Hopkins University Press, 1999), pp. 239-55.

${ }^{29}$ Ibid., p. 191.

${ }^{30}$ Ibid., pp. 191-92.

${ }^{31}$ Ibid., p. 191.

32 Though the ending of The Child might be the exception here

${ }^{33}$ Richard Rushton, 'Early, classical and modern cinema: absorption and theatricality’, Screen, vol. 45, no. 3 (2004), pp. 226-44; The Reality of Film: Theories of Filmic Reality (Manchester: Manchester University Press, 2011), pp. 63-78. ${ }^{34}$ Michael Fried, The Moment of Caravaggio (Princeton, NJ: Princeton University Press, 2010), p. 77. 
${ }^{35}$ See ibid., pp. 105-6. Fried also discusses ‘empathic projection’ at length in Four Honest Outlaws: Sala, Ray, Marioni, Gordon (New Haven, CT: Yale University Press, 2011), pp. 205-15.

${ }^{36}$ Fried, The Moment of Caravaggio, p. 39.

${ }^{37}$ See Fried's comments on Caravaggio's Boy Bitten by a Lizard, in The Moment of Caravaggio, pp. 9-10.

${ }^{38}$ Ibid., p. 39.

${ }^{39}$ Frédéric Bonnaud, 'Radical kindness’, trans. J. Robbins, Film Comment, 1 March 2012, p. 24.

${ }^{40}$ Gregory Currie offers a version of empathic projection that he calls a 'simulation hypothesis’. Gregory Currie, Image and Mind (Cambridge: Cambridge University Press, 1995,) pp. 144-61.

${ }^{41}$ Stanley Cavell, The Claim of Reason: Wittgenstein, Skepticism, Morality and Tragedy (New York: Oxford University Press, 1979), p. 423.

${ }^{42}$ Ibid., p. 425.

${ }^{43}$ Ibid., p. 428. 